\title{
Leadership style and employee readiness: basic factors of leadership efficiency
}

\author{
Marijana Rodić \\ University of Novi Sad, The Faculty of Economics in Subotica, Subotica, Serbia \\ Slobodan Marić \\ University of Novi Sad, The Faculty of Economics in Subotica, Subotica, Serbia
}

\begin{abstract}
The scope of this study is based on the Situational Leadership Theory according to the model created by Hersey and Blanchard, predominantly defined by two research sub-fields: leadership style and readiness of employees. This model distinguishes four different leadership styles, while the subject area of readiness of employees comprises two components: readiness of employees based on the competency component and readiness of employees based on a psychological (motivational) component. The subject matter of the study is to identify leadership style as a new variable which will be utilized for determining the interdependence with leadership efficiency levels and readiness of employees. Leadership efficiency is determined by the degree of compatibility between the dominant style of leadership and the level of readiness of employees. In addition to the main objective of the research, aimed at determining leadership efficiency, significant research findings come as a result of specific objectives. That is impact of the dominant leadership style on readiness of employees and leadership results, based on each specific component. The sample will be a random sample from a finite population of units, with repeated sampling and known probability sampling. A sample of size $n=100$, with a proportion of 0.10 , is based on a list of top 100 biggest companies in the Republic of Serbia in 2019. The application of Principal Component Analysis aims to identify new variables in the form of regression coefficient results, while the application of the hierarchical regression model will help determine the impact of each leadership style on readiness of employees. The study findings confirm the basic hypotheses of the aforementioned model, with regard to the results of leadership efficiency, as well as its impact of each leadership style on readiness of employees.
\end{abstract}

Keywords

Situational Leadership Theory (SLT), Hersey and Blanchard Model, leadership style, readiness of employees, leadership efficiency

\section{Introduction}

The chosen problem orientation of this paper is a consequence of the significant role that leadership has in the basic outcomes in the form of various success measures. As one of the functions of management, leadership has the most direct impact on achieving business goals at all levels of the organisation. The above mentioned does not mean that leadership is given exclusive dominance over other functional segments of the management process. Strategic management related to building and structuring the organization's resources predetermines the enterprise's potential pertaining to innovative ability (Leković \& Marić, 2016). However, the dominant economic circumstances and business conditions based on the importance of the human factor and knowledge are directly influenced by the leadership function. So, thus determining the business results and business success, they contribute to the importance of the leadership function. Direct results of employees feature as consequence of adequately performing a leadership role. 
Using several facts, primarily the importance of knowledge as a key factor of business and the main source of competitive advantage, on the one hand and unlimited human resources in the business process on the other, we can confirm the views that critical quantity is manifested by transformation into a new quality, especially when knowledge and the possibility of cognition are concerned. Unlike the traditional approach to leadership development, according to the above authors, it is necessary that all employees are involved and contribute to leadership development (Stojanović \& Marić, 2018). Furthermore, the area of motivation, which is a key factor of individual contribution, achieved results and goals. The fact that motivation has no upper limit provides sufficient reasons for the concept of leadership to be ever present in the scientific research of different kind. Also, taking into account the nature of this role presented in the above mentioned stances, as it provides a significant space for identifying sufficiently relevant and current research problems with significant essential importance. The problem (subject matter) of the research defined based on the construction of the research framework is the area of leadership efficiency. The form of harmonising leadership style and employee readiness, i.e. improving leadership efficiency to provide leadership results, is more complex in nature, at a higher level. The basic research question is as follows: To what extent is leadership efficiency determined by the compliance of leadership style and employee readiness?

The needs of current and future research based on the Situational Approach within the Hershey and Blanchard Leadership Theory, are created by limited empirical support (Graeff, 1997; Nahavandi, 1997; Northouse, 2007; Yukl, 2006; Papworth, Milne \& Boak, 2009) necessary for successful application and achievement of expected results. Also, significant space for new research is created due to the conflicting results of theoretical research. This is the case in the form of the presence and absence of a positive correlation between leadership efficiency and baseline results (Papworth et al. al., 2009; Vecchio, Bullis \& Brazil 2006; Goodson, McGee \& Cashman, 1989). Therefore, each new research represents a significant contribution to testing the reliability of the theoretical model based on the obtained research results enabling the identification of important situational factors. Both research result, existing and new, significantly affect leadership efficiency. Important situational factors of the model include the leadership style, employee readiness and business environment.

Within the field of leadership, numerous studies have been conducted with different approaches (Rowold \& Borgmann, 2013; Hallinger, 2011; Dierckx de Casterle, Willemse, Verschueren \& Milisen 2008; Nilsson \& Furaker, 2012; Brandt \& Laiho, 2013; Hoption, Barling \& Turner, 2013). Despite the numerous studies that have been conducted so far, the field of leadership still provides unlimited opportunities for new research and knowledge as well. As many situational factors are associated with the role of leadership, both definition and interpretation are not generally accepted. The essence of the Situational Approach to Leadership is reflected in the implications of each specific situation that requires an appropriate leadership style. Many behaviourist scholars (Reddin, 1967; Adair, 1973; Blake \& Mouton, 1982) believe that leadership can only be explained by a specific business situation. Leadership and organizational behavior stayed at pinnacle in the arena of organizational behavior research since decades and has attained significant consideration of scholars pursuing to define multifaceted dynamics of leadership and their influence on follower's behavior at work Majeed, Ramaya, Mustamil, Nazri \& Jamshed, 2017). The expected research results will provide a better knowledge and understanding of the selected model. A significant contribution is reflected in the increase of empirical results and getting to know all important situational factors of the organisational context. These factors can potentially be included in the model and thus contribute to its development. Assuming the choice of an adequate approach/model in leadership analysis, primarily in the context of practical results, as well as application of the appropriate research concept. A significant space for improving leadership efficiency can be identified through direct results, primarily measured by employee performance.

\section{Dominant views in the field of research - compliance of leadership style and employee readiness as an initial measure of leadership efficiency}

The selected model of Situational Leadership Theory represents a very complex prism of 
analysis of leadership practice and baseline results in order to obtain relevant facts through the research process, which will enable comprehensive definition of the state of affairs in the field of research and provide specific and precise guidelines necessary for requested improvements. Improvement occurs if the manager applies a leadership style that is best aligned with the readiness of employees, which means an appropriate level of ability in the form of competence, or on the other hand, the possibility and psychological factor in the form of commitment of subordinates, which leads to higher performance and employee satisfaction. A proper connection between these two elements gives good results both at the level of the organisation and at the level of the individual person.

Hersey and Blanchard's (1969; Hersey, Blanchard \& Johnson, 2001) model of situational leadership is one of the best-known approaches to leadership (Bass, 1990; Northouse, 2004; Vecchio, 1987; Yukl, 2006; Kaifi, Noor, Nguyen, Aslami \& Khanfar, 2014). This model is used as a major tool in training and development programmes in over 400 companies in the Fortune 500 list (Hersey et al., 2001; Lacey, 2019). Leadership style is a very important characteristic of managers (Lam \& O'Higgins, 2012). In Situational Theory, the best leadership style is one that is adapted to the identified elements of a specific situation. The basic approaches of Situational Leadership Theory (STL) include Fiedler's Leadership Theory (1967), Path-Goal Leadership Theory (House, 1971), and Hersey and Blanchard's Situational Leadership Theory (Hersey \& Blanchard, 1984). According to the Hershey and Blanchard's Situational Leadership Theory, there is a view that most leaders prefer a leadership style that is appropriate to the specific situation. The focus of the STL is on the interaction between the leader behaviour and employee readiness, which basically determines the effectiveness of leadership (Blank, Weitzel \& Green, 1990). According to the basic principles of situational leadership, there is no single leadership style. Based on the above, there is no leadership style or model that matches every situation since the appropriate style is based on employee characteristics and the nature of business tasks, as a result of which all identified leadership styles have different levels of guiding behaviour and support (Farmer, 2005).

The situational leadership model creates four forms of behaviour that are the result of two dimensions, namely support that can be expressed at high and low levels (listening, providing feedback and encouragement) and guidance that can be represented at the level between two extremes in the form of instruction, training and monitoring (Hersey \& Blanchard, 1984). Within this model, it is important to define three key competencies, namely: leadership diagnosis ability, flexibility and partnership in execution. So far, an evolutionary approach has identified three phases in the development of SLT (Thompson \& Vecchio, 2009). The first original version of Situational Leadership Theory was presented by Hershey and Blanchard. In a newer version called SLT - II, exclusively created by Blanchard (2007), there is a modification in the relationship between leader behaviour and employee maturity. The essence of this version is reflected in the fact that the author introduces four developmental levels of employees (Blanchard, 2007; Thompson \& Vecchio, 2009; Papworth et al., 2009), namely: (I) a beginner with enthusiasm, (II) a student without illusions, (III) a careful but capable employee and (IV) an employee with confidence. Of course, these four levels of employee development are retained by these authors in combination with the four basic leadership styles. The third generation of the SLT - III indicates possible different responses of employees in terms of the autonomy provided to them by the leader.

The objective of Situational Leadership Theory is to connect or harmonise the adequate leadership style with the achieved level of development of each individual, taking into account the defined individual goals and tasks. Therefore, SLT strives to apply an appropriate leadership style depending on the possible four development levels of employees. Accordingly, the role of the leader is reflected in providing the necessary guidance and support in order for employees to achieve continuity in development. This means that the leadership style needs to be changed in accordance with the change in the developmental level of each individual. This implies, above all, that there is no best style of leadership because each individual has a certain level of development depending on the nature of the individual goal and task. Thus, the model of Situational Leadership Theory is presented as a partnership based on the understanding of needs, which are determined in accordance with the nature of the work of each individual, by the leader. 


\subsection{Advantages and disadvantages of Situational Leadership Theory}

With regard to SLT - II, several positive features can be identified, such as: (1) implementation of a development level framework that allowed leaders to better determine employee performance levels, (2) based on the first quadrant, the SLT and leadership style subsequently allow leaders adequate influence on employees based on style and behaviour. (3) Furthermore, the SLT - II emphasises flexibility by allowing leaders to adapt their own style to meet the needs of employees. (4) The development and performance of the lowest organisational level line is improved owing to employees (Graeff, 1983). In addition to the advantages of the model, there are certain shortcomings, such as: (1) lack of published research at the SLT - II level, indicating lack of information which limits support for basic conceptual assumptions, (2) additional research is needed to improve understanding of interdependence of competencies and task performance, (3) publication of standard results by common tools, (4) linking studies that explore the developmental level of specific goals and tasks, and (5) demographic studies inadequately explain how characteristics affect a leader (Boatwright \& Vecchio, 2002) .

In addition to the mentioned advantages and disadvantages of the SLT model according to the approach of Hensri and Blanchard in terms of the assessment of the validity of the selected model and the whole defined framework, numerous criticisms of both theoretical views and empirical results can be mentioned. Based on the Leader Behaviour Analysis (LBA) scale, a positive correlation between the situational leadership style and the perception of employee performance by managers is emphasised. The said authors argue that the situations in which the model of Situational Leadership Theory was adequately applied, the performance of employees was at a significantly higher level. By using creative methods of content analysis to interpret the success of the leader/employee interaction, primarily in the form of improving employee readiness, leaders tend to be less dominant in terms of management style (Papworth et al., 2009). In addition to highlighting the increase in employee readiness, the results of this analysis also emphasise the fact that task-oriented leader behaviour becomes less represented and is directly related to the perception of the model. These views are supported by research the results of which indicate that leaders who use a more adaptable and flexible style are rated as more successful than traditional managers who have a rigid style, which is manifested at the organisational level in terms of greater success (Silverthorne, 2000; Silverthorne \& Wang, 2001). Also, there are results that indicate that SLT emphasises the flexibility of leaders far more, while the results of the research we refer to largely support the existing theory of leadership compared to all other situational theories of leadership. The situational leadership model has been used as a basis for a contextual leadership method that suggests an increased level of concordance between employee readiness and leadership style determined by task or employee orientation (Ralph, 2004). Also, more current research and results confirm previous assumptions in the sense that the application of this model has a positive impact on the matching leadership style and employee readiness (Luo \& Lio, 2014). The general attitude regarding the analysis of the chosen approach and leadership model, regardless of the limited scope of research dedicated to this area, shows that there is an increase in empirical results that confirm the validity of Hensri and Blanchard's Situational Leadership Theory Life Cycle model.

The basic starting point of the research concept based on the situational approach of Hershey and Blanchard - this model of leadership indicates that the success of leadership is determined by the experience of the manager / superior officer (Rosiński, 2017), which implies the ability to match leadership style (Tortorella \& Fogliatto, 2017; Lacey, 2019).

\subsection{Leadership style and employee readiness}

Accordingly, there is no such thing as the best style, approach or way of influencing subordinates/employees, but it is necessary to have adequate competence of the leader to identify all the important elements naturally manifested by the business situation, dominant readiness of employees, and accordingly apply the appropriate leadership style. It can be concluded from the above mentioned that subordinates define the behaviour of managers, while, on the other hand, managers have absolute responsibility for the adequacy of subordinates in terms of knowledge, skills and abilities. In line with the above interpretation, Hershey and Blanchard (1969) developed a Life Cycle of Leadership 
Theory based on a three-dimensional concept of leadership theory that was later renamed Situational Leadership Theory by the same authors. The research aspirations manifested in such fashion, based on the approach of Situational Leadership Theory and the model of Hershey and Blanchard, make correlation between the effectiveness of leadership, as a measure of leadership style and employee readiness, which is widespread as a leadership development programme in many organisations. Mass use of the model is a consequence of the possibility of practical application and adaptation to specific circumstances, where generalisation is not possible. While on the other hand, the usefulness of the model is reflected primarily in its evolutionary maturity, as a theoretical concept from which a reliable tool has developed, as well as in the extreme complexity that fully corresponds to the situational approach and provides the opportunity to respect the different nature of situational factors (Hersey \& Blanchard (1969; Hersey et al., 2001). The situational leadership model comprises three dimensions.

The two dimensions are related to the leadership style defined by a combination of two patterns of behaviour, both interpersonal and businessoriented. By combining these two models of behaviour, four leadership styles are established: Commanding style (S1: Z +, O-); Teaching style (S2: Z +, O +); Support style (S3: Z-, O +); Delegation style (S4: Z-, O-). According to this model, the most effective leadership style is determined by the readiness that employees (subordinates) show. Employee readiness is a combination of two components, psychological and competence components, as a result of which four developmental levels are formed: R1 - lack of competences and lack of readiness (motivation), R2 - lack of competences and present readiness (motivation), R3 - present competence without readiness (motivation) and R4 - present competence and readiness (motivation) (Blanchard, 2007; Blanchard, 2010; Thompson \& Vecchio, 2009; Papworth et al., 2009; Thompson \& Glaso, 2015).

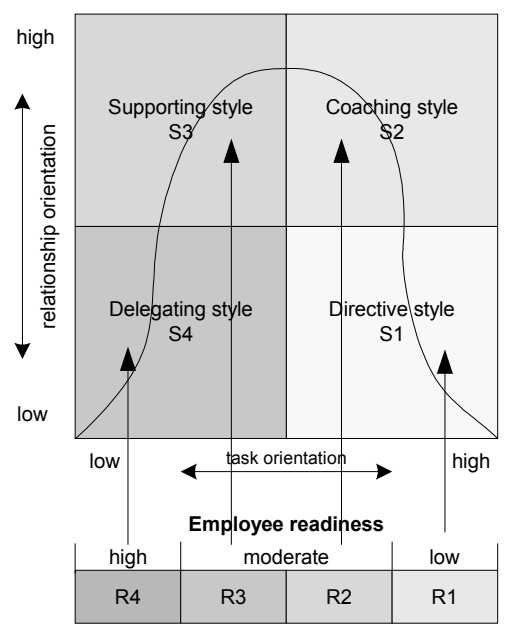

Figure 1 Hersey and Blanchard's Situational Leadership Mode Source: Blanchard, 2007

Thus, the readiness of employees determines the specific style of leadership, as illustrated in the presentation, and the adequate harmonisation of leadership style and the level of readiness of employees determines the effectiveness of leadership. The original version of the Hersey and Blanchard normative model indicates that leadership style should be related to employee maturity (Hersey \& Blanchard, 1977). In the latest version, the category of "maturity" has been replaced by the far more specific term "readiness" (Hersey, Blanchard \& Johnson, 1996, 2013). There is no strict distinction between these two terms, since both terms are used in the theoretical discussion of the current references. Four levels of maturity require the application of four different leadership styles. Employees with the lowest level of readiness, R1, are not willing (motivated) and do not have the ability (competence) to perform tasks. In this case, the leader is expected to apply the S1 command style, which implies maximum orientation to the work task and minimum orientation to employees. At the core of this approach is the creation of a structure which provides specific and explicit guidance on workoriented focus (Hersey et al., 2013). Moderate level of readiness of employees at the R2 level, includes a high level of motivation and low level of competences. With the appropriate leadership style being S2, training manifests itself in a great focus on both the task and the employees. By applying this style, leaders use dominant persuasion based on trust, explaining the importance of the task to employees and showing attention to maintaining the required level of motivation. When employees reach a higher level 
of readiness, in the $\mathrm{R} 3$ category, then leaders have a need to involve employees in the decisionmaking process. This situation is characteristic of the S3 leadership style, where leadership support and maximum focus on employees dominate. Employees have a sufficient amount of knowledge, i.e. they are fully competent for the necessary successful problem solving when performing work tasks. Employees with the highest level of readiness, R4, are highly competent individuals in their field, they are highly motivated and capable of performing work independently. The behaviour or leadership style that best suit this category of employees is the style of delegation. This style is characterised by a low level of focus on both the task and the employees. It is reflected in a significant level of delegation of competences and responsibilities to employees, which results in independent decisionmaking of employees.

In Situational Leadership Theory, leadership efficiency is achieved if the manager uses a leadership style that is best related to employee readiness, i.e. motivation and ability. The best compliance of the stated elements of the Situational Leadership Theory ensures a high level of employee satisfaction and performance. It is obvious that by increasing the readiness of employees, leadership behaviour contains a lower level of structure (task orientation) and a smaller volume of social and emotional support (employee orientation). Leadership behaviour directed towards two possible extremes in interaction with the readiness of employees significantly affects the efficiency of leaders, which is defined as the effort with which employees show the ability and motivation to perform specific tasks. According to this theory, in the case of employees with a low level of readiness, leaders need to provide specific guidelines, while in the case of a high level of readiness, employees become responsible for specific tasks. Thus, there is definitely no best way to influence employees, which is why leaders have the need to assess the readiness of employees and accordingly choose to apply the appropriate leadership style. Therefore, in accordance with psychological and competence factors, it is argued that employees determine the appropriate style of leadership behaviour.

Considering all the above mentioned factors, the effectiveness of leadership is provided by the degree of harmonisation of leadership style and readiness of employees (subordinates)
(Salehzadeh, Shahin, Kazemi \& Shaemi Barzoki, 2015; Salehzadeh, 2017; Luo \& Liu, 2014, Lacey, 2019). The influence of leadership style on work performance and job satisfaction has a significant, both theoretical and practical grounds. This influence of leadership is manifested at the level of the organisation, department or smaller groups such as teams in the form of work atmosphere or psychological climate. If they want to achieve positive and noticeable results in the field of leadership, individuals as bearers of this role cannot be determined for one general style (Goleman, 2000; Cote, 2017, Chivu, 2019). The principles of Situational Leadership Theory suggest that effective leadership is a function of the level of readiness of employees, which is based on traditional theories of motivation since individuals of different developmental levels have respectively different needs. In accordance with the abovementioned, these differences in needs result in different results even though individuals work under the same conditions on the same tasks.

\section{Methodology}

The basic research set, which by its nature has all the features of a closed population due to the defined final number of members, is given in the form of employees / individuals of the 100 largest companies in the Republic of Serbia in 2019, with selected view values on the given scale of observed characteristics/variables grouped within the research unit of the general research space. The basic set of selected companies defined in this way is based on common criteria such as the balance sheets from the previous year, the ranking of small, medium and large companies, revenue, profit, export value and number of employees.

Data on the criteria for defining the basic set are provided by CUBE TEAM, as the leading provider of business and credit information in the Republic of Serbia. In this manner, the basic set is methodologically grounded, since its definition is based on content, scope and time frame. The values of parameters in the form of quantitative units, as aggregate descriptive features of the basic set, will be provided on the basis of data obtained by testing the sample.

The sampling draft will primarily take into account the properties of the base set, while the sample will have the characteristics of a random sample of the final base set, with a sample plan with repetition and a known sampling probability. 
A sample of size $\mathrm{n}=100$ will have the characteristics of a proportional stratified sample, with a size of 0.10 , because the list of 100 companies will be divided into 10 groups, by tens, so that the respondents of companies of different success levels are evenly represented. The selection of companies in each group will be based on the criteria of alphabetical order, and the strata within the selected company will be completed by the immediate respondents according to the snowball principle.

From the point of view of research feasibility and sample economy, for the purpose of quantitative procedures and statistical inference, the sample size can be considered sufficient in this predominantly exploratory research, since factor analysis of measurement scales requires 10 - 40 sample units per variable (research unit) included in model.

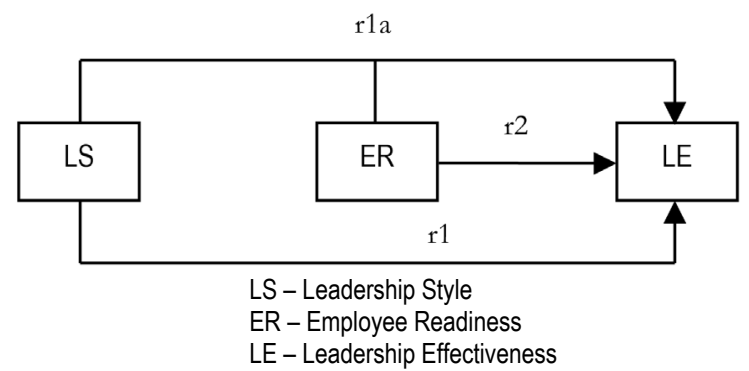

Figure 2 Conceptual framework of research Source: The authors

Taking into account the structure of the research area and the relations established between the parts, research subunits, the basic hypotheses are defined, which will be elaborated or analysed during the presentation of the theoretical ruling positions of the research area for a more comprehensive research within the general research problem. Selected features/variables, grouped within the research units forming the questionnaire will enable inference as a consequence of conducted research and data analysis using a selected set of quantitative procedures aimed at examining the set relations in the form of the following research assumptions:

H1: There is a statistically significant interdependence between leadership style and leadership efficiency;

H1a: There is a statistically significant interdependence between leadership style and employee readiness and leadership efficiency; The hypotheses $\mathrm{H} 1 \mathrm{(r1}$ ) and H1a (r1a) will be tested with hierarchical regression.

$\mathrm{H} 2$ : There is a statistically significant interdependence between employee readiness and leadership efficiency. The hypothesis H2 (r2) will be tested with multiple regression. For the purpose of the research, a list of 24 variables from two research units divided into two research scales was selected. The scales used have an acceptable internal agreement, which are the results in Table 1.

Table 1 Reliability Statistics

\begin{tabular}{l|c|c|c}
\hline \multicolumn{2}{l|}{ Cronbach's Alpha } & $\begin{array}{c}\text { Cronbach's Alpha } \\
\text { Based on Standardized } \\
\text { Items }\end{array}$ & $\begin{array}{c}\mathrm{N} \text { of } \\
\text { Item } \\
\text { s }\end{array}$ \\
\hline LeadStyle &, 861 &, 873 & 12 \\
\hline EplRed &, 888 &, 902 & 12 \\
\hline LeadScore &, 756 &, 768 & 12 \\
\hline \multicolumn{3}{|c}{ Source: The authors' calculation }
\end{tabular}

One scale of research covers the research unit of leadership with two segments, namely leadership style and leadership efficiency (LEAD Other Scale, Hersey et al., 1996), while the other scale examines the readiness of employees (Readiness Scale - Staff Member Rating Scale, Hersey et al., 1996).

Table 2 Total Variance Explained

\begin{tabular}{l|r|r|r|r|r|r|r}
\hline Component & \multicolumn{4}{|c|}{ Initial Eigenvalues } & \multicolumn{2}{c|}{ Extraction Sums of Squared Loadings } & \multicolumn{2}{c}{$\begin{array}{c}\text { Rotation Sums of } \\
\text { Squared Loadings }\end{array}$} \\
\cline { 2 - 7 } & Total & $\begin{array}{c}\text { \% of } \\
\text { Variance }\end{array}$ & Cumulative \% & Total & \% of Variance & $\begin{array}{c}\text { Cumulative } \\
\%\end{array}$ & Total \\
\hline 1 & 6.912 & 34.558 & 34.558 & 6.912 & 34.558 & 34.558 & 6.906 \\
\hline 2 & 2.543 & 12.716 & 47.274 & 2.543 & 12.716 & 47.274 & 2.547 \\
\hline
\end{tabular}

Extraction Method: Principal Component Analysis.

a. When components are correlated, sums of squared loadings cannot be added to obtain a total variance.

Source: The author's calculation

Due to the number of variables, the selection of variables was performed in accordance with the research concept, and a quantitative analysis was conducted in order to group the selected variables using factor analysis based on the PCA (principal components analysis) approach. As a result of the analysis of this method, two factors (groups of variables) were singled out, i.e. two new variables 
were formed, namely leadership style and employee maturity. The advantage of choosing factor analysis as an auxiliary research method is reflected in the possibility of forming new, more complex variables that represent more complex phenomena, as opposed to the basic method, hierarchical regression that examines the interdependence of individual features relationships of which are represented by the research model.

\section{1. Analysis of research results and discussion}

Using the principal components method (PCA), 24 variables from two areas were analysed, namely employee maturity and leadership style. Prior to conducting specific factor analysis procedures, the suitability of a data set based on the CMO indicator (Kaiser-Meyer-Olkin Measure of Sampling Adequacy) the value of which is 0.621 was examined, which exceeds the value of 0.6 (Kaiser, 1974) and the significance indicator (Bartlett's Test of Sphericity) with a significance level of $p=0.000$, since the limit of acceptability is Sig. $<0.05$ (Bartlett, 1954). The stated values of previous analyses indicate the factorability of the correlation matrix, i.e. the justification of quantitative procedures of factor analysis of the selected method applied to the set of available data as an auxiliary method for confirming two subsets of variables from these areas examined by separate scales. There is also the suitability of the correlation matrix of the selected

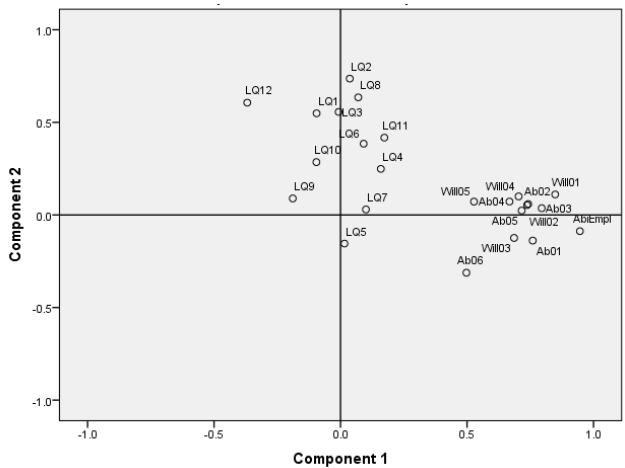

Figure 3 Diagram of components after rotation Source: Author's calculation

variables for factorisation, since examination can isolate a significant number of correlation values of the variables at a level higher than $r=$ 0.3 . These quantitative procedures in this case were performed in two iterations.

They differed in the fact that in the first procedure, the number of selection factors was not limited. Then, 8 factors with specific values over 1 were identified, which explain cumulatively $80.46 \%$ of the variance, where the first two have a higher value compared to the remaining 6 , which is $47.27 \%$. Due to the inadequate number of components, based on the Scree plot, it could be detected that there is an obvious break in the line of the diagram between the second and third points, which indicates the justification for reducing the number of components to two.

Table 3 Pattern Matrix ${ }^{a}$ - Rotated Component Matrix

\begin{tabular}{l|r|r}
\hline \multirow{2}{*}{} & \multicolumn{2}{|c|}{ Component } \\
\cline { 2 - 3 } & \multicolumn{1}{|c|}{1} & \multicolumn{1}{c}{2} \\
\hline Ability level & .946 & -.088 \\
\hline Degree of self-confidence... & .848 & .111 \\
\hline Skill level... & .795 & .036 \\
\hline Scope of knowledge... & .760 & -.139 \\
\hline Scope of experience... & .742 & .059 \\
\hline Degree of commitment... & .737 & .053 \\
\hline Timely execution... & .716 & .024 \\
\hline Taking responsibility... & .704 & .100 \\
\hline Degree of motivation... & .686 & -.124 \\
\hline Degree of independence... & .668 & .072 \\
\hline Scope of jurisdiction & .527 & .072 \\
\hline Reporting frequency... & .497 & -.312 \\
\hline C\#2: Level of results... & .036 & .736 \\
\hline C\#8: Manager's confidence... & .070 & .635 \\
\hline C\#12: Bad employee relations & -.369 & .606 \\
\hline C\#3: Troubleshooting... & -.008 & .556 \\
\hline C\#1: The nature of communication... & -.095 & .549 \\
\hline C\#11: Promotion of a new manager... & .173 & .417 \\
\hline C\#6: New manager... & .091 & .385 \\
\hline C\#10: Taking responsibility of employees... & -.095 & .285 \\
\hline C\#4: Implementing change... & .159 & .249 \\
\hline C\#9: Improving results... & -.189 & .089 \\
\hline C\#7: Changes in jurisdiction... & .100 & .030 \\
\hline C\#5: Relation to results... & .016 & -.155 \\
\hline Extraction Method: Principal Component Analysis. & & \\
Rotation Method: Oblimin with Kaiser Normalization. & & \\
a. Rotation converged in 4 iterations. & & \\
& & \\
\hline
\end{tabular}

Source: The author's calculation

Within both identified factors, variables with significant factor weights are present, most of them above 0.5 (acceptable limit above 0.3 ). When analysing these two components, the acceptable interpretation could be that the selected variables are justifiably grouped and adequately represent by two components, namely leadership style with variables with factor weights ranging from 0.385 to 0.736 , then the employee readiness component with respectable variables with factor weights ranging from 0.497 to 0.946 .

In the sequential assessment of the impact of the two basic features of predictor and mediator status, leadership style and employee readiness for 
leadership efficiency, multiple hierarchical regression was used in relations 1 and 1a of the said research framework. Other features had an auxiliary character in confirming the reliability of relations, such as age, education, position and area of education. In the first step of the hierarchical regression, the variable readiness of employees was missing, which influenced the coefficient of determination to be $\mathrm{R}^{2}=10.10 \%$, i.e. the model contributes to the explanation of $10.10 \%$ of the variance of leadership efficiency. After adding the feature of employee maturity in the second step of the procedure, the model as a whole explained $\mathrm{R}^{2}$ $=31.10 \%$ of the total variance of the specified dependent variable. Thus, the additional feature of employee maturity explained additional $\mathrm{R}^{2}$ change $=21.00 \%$ of the variance of leadership efficiency, which is significant contribution confirmed by the value of the indicator Sig. F change, $\mathrm{p}=0.000$. ANOVA indicates that the model as a whole is statistically significant with values of $F(5 ; 78.432)=2,328, p=0.0002$. When evaluating each independent variable, the obtained results indicate a statistically significant contribution of only three variables, leadership style (0.02), employee readiness $(0.02)$ and area of education (0.05).

The $\mathrm{r} 2$ relation was evaluated by a multiple regression procedure, where the impact of employee maturity on leadership efficiency was assessed as the basic features of the model, while the auxiliary features contributed to the reliability of the assessment. The coefficient of determination of the model has the value $\mathrm{R}^{2}=$ $9.5 \%$, which indicates that the model explains $9.5 \%$ of the variance of the dependent variable, in this case the efficiency of leadership. The value of the coefficient of determination is on the limit of acceptability for the area of the observed phenomenon. The values of the ANOVA indicator show that the model as a whole is statistically significant with $\mathrm{F}(4 ; 84.071)=2.478, \mathrm{p}=0.0004$. When evaluating the contribution of each independent variable in the prediction of the dependent variable, the obtained results indicate a statistically significant value of the two variables, employee readiness (0.03) and area of education (0.05).

Table 4 Results Multiple (2), Hierarchical Regression (1)

\begin{tabular}{l|l|l|l}
\hline Parameters for model evaluation & Model $1 / \mathrm{r} 1$ & Model 1a/r1a & Model 2/2 \\
\hline $\mathrm{R}^{2}$ & 0,101 & 0,311 & 0,095 \\
\hline $\mathrm{R}^{2} \Delta$ (change) & 0,101 & 0,210 & \\
\hline ANOVA $^{1 \mathrm{~A}}$ & & $\mathrm{~F}(5 ; 78.432)=2.328$ & $\begin{array}{l}\mathrm{F}(4 ; 84,071)=2,478 \\
\mathrm{P}=0,0004\end{array}$ \\
\hline Leadership style (RFS) & & $0.020^{*} \quad$ & \\
\hline Employee readiness (RFS) & & $0.029^{*}$ & $0,030^{*}$ \\
\hline Education & & 0.240 & 0,282 \\
\hline Area of education & & $0.046^{*}$ & $0,050^{*}$ \\
\hline Age & & 0.172 & 0.780 \\
\hline
\end{tabular}

Dependent variable: leadscore: leadership efeciency - leadership effectiveness

Predictors: (constant), leadership style (rfs); education, area of education, age (control variables) ${ }^{1}$

Predictors: (constant), leadership style (rfs); education, area of education, age (control variables), employee readiness) (mediator) $\mathrm{rfs}^{1 \mathrm{a}}$

In the sequential assessment of the impact of the two basic features of predictor and mediator status, leadership style and employee readiness for leadership efficiency, multiple hierarchical regression was used in relations 1 and 1a of the said research framework. Other features had an auxiliary character in confirming the reliability of relations, such as age, education, position and area of education. In the first step of the hierarchical regression, the variable readiness of employees was missing, which influenced the coefficient of determination to be $\mathrm{R}^{2}=10.10 \%$, i.e. the model contributes to the explanation of $10.10 \%$ of the variance of leadership efficiency.

After adding the feature of employee maturity in the second step of the procedure, the model as a whole explained $\mathrm{R}^{2}=31.10 \%$ of the total variance of the specified dependent variable. Thus, the additional feature of employee maturity explained additional $\mathrm{R}^{2}$ change $=21.00 \%$ of the variance of leadership efficiency, which is significant contribution confirmed by the value of the indicator Sig. $F$ change, $p=0.000$. ANOVA indicates that the model as a whole is statistically significant with values of $F(5 ; 78.432)=2.328, p$ $=0.0002$. When evaluating each independent variable, the obtained results indicate a statistically significant contribution of only three variables, leadership style (0.02), employee readiness $(0.02)$ and area of education $(0.05)$. 
The $\mathrm{r} 2$ relation was evaluated by a multiple regression procedure, where the impact of employee maturity on leadership efficiency was assessed as the basic features of the model, while the auxiliary features contributed to the reliability of the assessment. The coefficient of determination of the model has the value $\mathrm{R}^{2}=$ $9.5 \%$, which indicates that the model explains $9.5 \%$ of the variance of the dependent variable, in this case the efficiency of leadership.

Table 5 T test of independent samples - (In) compliance with leadership style and employee readiness

\begin{tabular}{|c|c|c|c|c|c|c|c|c|c|c|}
\hline & & \multicolumn{2}{|c|}{$\begin{array}{c}\text { Levene's Test for } \\
\text { Equality of Variances }\end{array}$} & \multicolumn{7}{|c|}{ t-test for Equality of Means } \\
\hline & & \multirow[t]{2}{*}{$\mathrm{F}$} & \multirow[t]{2}{*}{ Sig. } & \multirow[t]{2}{*}{$t$} & \multirow[t]{2}{*}{$\mathrm{df}$} & \multirow{2}{*}{$\begin{array}{c}\text { Sig. } \\
(2- \\
\text { tailed) }\end{array}$} & \multirow[t]{2}{*}{$\begin{array}{c}\text { Mean } \\
\text { Difference }\end{array}$} & \multirow[t]{2}{*}{$\begin{array}{l}\text { Std. Error } \\
\text { Difference }\end{array}$} & \multicolumn{2}{|c|}{$\begin{array}{c}95 \% \text { Confidence Interval } \\
\text { of the Difference }\end{array}$} \\
\hline & & & & & & & & & Lower & Upper \\
\hline \multirow{2}{*}{ Age } & $\begin{array}{l}\text { Equal variances } \\
\text { assumed }\end{array}$ & 1.940 & , 167 & -2.563 & 98 & .012 & -7.145 & 2.787 & -12.676 & -1.613 \\
\hline & $\begin{array}{l}\text { Equal variances } \\
\text { not assumed }\end{array}$ & & & -3.231 & 22.034 & .004 & -7.145 & 2.211 & -11.729 & -2.560 \\
\hline \multirow{2}{*}{ Education } & $\begin{array}{l}\text { Equal variances } \\
\text { assumed }\end{array}$ & .086 & ,770 & -.872 & 98 & .386 & -.146 & .168 & -.479 & .187 \\
\hline & $\begin{array}{l}\text { Equal variances } \\
\text { not assumed }\end{array}$ & & & -1.038 & 20.559 & .311 & -.146 & .141 & -.440 & .147 \\
\hline \multirow{2}{*}{ LeadScore } & $\begin{array}{l}\text { Equal variances } \\
\text { assumed }\end{array}$ & .016 & ,899 & -1.682 & 98 & .096 & -2.880 & 1.713 & -6.279 & .519 \\
\hline & $\begin{array}{l}\text { Equal variances } \\
\text { not assumed }\end{array}$ & & & -1.657 & 17.316 & .116 & -2.880 & 1.738 & -6.543 & .782 \\
\hline \multirow{2}{*}{$\begin{array}{l}\text { Leadership } \\
\text { Style RFS }\end{array}$} & $\begin{array}{l}\text { Equal variances } \\
\text { assumed }\end{array}$ & 3.158 & ,079 & -.642 & 97 & .523 & -.18562596 & .28930211 & -.75981057 & .38855865 \\
\hline & $\begin{array}{l}\text { Equal variances } \\
\text { not assumed }\end{array}$ & & & -.884 & 25.244 & .385 & -.18562596 & .21008495 & -.61809203 & .24684011 \\
\hline \multirow{2}{*}{$\begin{array}{l}\text { Employee } \\
\text { Readiness } \\
\text { RFS }\end{array}$} & $\begin{array}{l}\text { Equal variances } \\
\text { assumed }\end{array}$ & 17.955 &, 000 & 8.530 & 97 & .000 & 1.86939477 & .21914323 & 1.43445611 & 2.30433342 \\
\hline & $\begin{array}{l}\text { Equal variances } \\
\text { not assumed }\end{array}$ & & & 5.787 & 14.427 & .000 & 1.86939477 & .32303529 & 1.17847265 & 2.56031688 \\
\hline
\end{tabular}

Source: The authors' calculation

The value of the coefficient of determination is on the limit of acceptability for the area of the observed phenomenon. The values of the ANOVA indicator show that the model as a whole is statistically significant with $F(4 ; 84.071)=$ 2.478, $\mathrm{p}=0.0004$. When evaluating the contribution of each independent variable in the prediction of the dependent variable, the obtained results indicate a statistically significant value of the two variables, employee readiness $(0.03)$ and area of education (0.05).

The available data for the observed variables or features allow additional analyses by which we can determine the effectiveness of leadership and then examine which variables contribute the most to the obtained result. Leadership efficiency is determined by the compliance of leadership style and employee readiness. With the determination of this variable, individual cases are divided into two groups, namely respondents where there is a match of leadership style and level of readiness of employees and a group of respondents where compliance is not present. By applying the $\mathrm{T}$ test of independent samples for the previously mentioned two groups of respondents, an attempt is made to determine the difference in terms of dependent features such as age, education, leadership result (situation assessment), leadership style (RFS) and employee readiness (RFS). Also, the aim is to determine the magnitude of the influence of variables in which the difference was identified. By comparing these two groups of cases where the compliance of leadership style is evident and where it is not, a statistically significant difference was found in two of the five analysed variables. A significant difference was found for the Age variable, where in the case of compliance $(\mathrm{M}=34.79$; $\mathrm{SD}=7.224)$ or noncompliance $(\mathrm{M}=41.93 ; \mathrm{SD}=9.993)$ the value of the $\mathrm{t}$ - test result is $\mathrm{t}(100)=-2.563, \mathrm{p}=0.012$, while the difference between the mean values of the features by groups is $\mathrm{MD}=-7.145$ and the confidence interval at the level of $95 \%:-12.676$ to -1.613 , with the magnitude of the impact and the value of the square eta $=0.027$, the difference in leadership compliance explains $2,7 \%$ of the age variance.

For the variable Readiness of employees, a significant difference was found, where in the case of compliance $(\mathrm{M}=1.61 ; \mathrm{SD}=1.18)$ or noncompliance $(\mathrm{M}=-0.26 ; \mathrm{SD}=0.67)$, the value of the $\mathrm{t}$ - test result is $\mathrm{t}(100)=5,787, \mathrm{p}=0,000$, 
while the difference between the mean values of the features by groups is $\mathrm{MD}=1.869$ and the confidence interval at the level of $95 \%$ : 1.178 to 2.560 , with the magnitude of the impact and the value of the square $=0.056$, i.e. the difference in leadership compliance explains $5.6 \%$ of the variance of employee readiness. In addition to the analysed five characteristics, the readiness of employees stands out as dominant in terms of achieving an impact on the effectiveness of leadership, which once again confirms the stated theoretical grounds.

\section{Conclusion}

The selected model of Situational Leadership Theory represents a very complex prism of analysis of leadership practice and baseline results in order to reach relevant facts through the research process, which will enable comprehensive definition of the situation in the field of research and provide specific and precise guidelines necessary for required improvements. Improvement occurs if the manager applies a leadership style that is best aligned with the readiness of employees, which implies an appropriate level of ability in the form of competence, or on the other hand the possibilities and the psychological factor in the form of commitment of subordinates. The set research relations between the subunits of the research area form the basic concept of the paper, which is quantitatively evaluated and confirmed at the level of statistical significance by accepting all three research assumptions. The results indicate that there is a statistically significant interdependence between leadership style and leadership efficiency where employee maturity plays an important role as a mediator variable that further confirms this relationship and contributes to a more detailed analysis and understanding of the research framework.

The results of research obtained by collecting, processing and analysing data should primarily contribute to understanding the existing leadership style in a particular company and identifying levels of efficiency, getting to know all the essential elements of the situational model to make the necessary adjustments to improve leadership practice. Also, research results should strikingly highlight the specific nature of leadership style, the impact of situational factors, and underlying outcomes as direct consequences of leadership. The results of the research, in the form of specific guidelines based on the identification and definition of existing leadership practices, are expected to be absolutely applicable within the research area. As implication, significant contribution is reflected in the increase of empirical results and getting to know all important situational factors of the organisational context. These factors can potentially be included in the model and thus contribute to its development. Current and future research are limited empirical support necessary for successful model application and achievement of expected results.sm

\section{References}

Adair, J. (1973). Action-Centred Leadership. New York: McGraw-Hill.

Bartlett, M. (1954). A note on the multiplying factors for various chi-square approximations. Journal of the Royal Statistical Society, 16 (2), 296-298.

Bass, B. (1990). Bass and Stogdill's Handbook of Leadership (3rd ed.). New York: The Free Press.

Blake, R.R., \& Mouton, J.S. (1982). A Comparative Analysis of Situationalism and 9,9 Management by Principle. Organizational Dynamics, 10 (4), 20-43. https://doi.org/10.1016/0090-2616(82)90027-4

Blanchard, K.H. (2007). Leading at a Higher Level. Upper Saddle River, N.J: Prentice-Hall.

Blanchard, K.H. (2010). Leading at A Higher Level. Upper Saddle River, N.J: Prentice-Hall.

Blank, W., Weitzel, J.R., \& Green, S.G. (1990). A test of the situational leadership theory. Personnel Psychology, 43 (3), 579-597. https://doi.org/10.1111/i.17446570.1990.tb02397.x

Boatwright, K.J., \& Vecchio, R.P. (2002). Preferences for idealized styles of supervision. The Leadership Quarterly, 13(4), 327-342. https://doi.org/10.1016/S1048-9843(02)00118-2

Brandt, T., \& Laiho, M. (2013). Gender and personality in transformational leadership context: an examination of leader and subordinate perspectives. Leadership \& Organization Development Journal, 34 (1), 44-66. https://doi.org/10.1108/01437731311289965

Chivu, L. (2019). Local entrepreneurship and social services in Romania. Territorial analysis. European Research on Management and Business Economics, 25 (2), 79-86. https://doi.org/10.1016/j.iedeen.2019.04.001

Cote, R. (2017). A comparison of leadership theories in an organizational environment. International Journal of Business Administration, 8 (5), 28-35. https://doi.org/10.5430/ijba.v8n5p28

Dierckx de Casterle, B., Willemse, A., Verschueren, M., \& Milisen, K. (2008). Impact of clinical leadership development on the clinical leader, nursing team and care-giving process: a case study, Journal of Nursing Management, 16 (6), 753-763. https://doi.org/10.1111/j.1365-2834.2008.00930.x

Farmer, L.A. (2005). Situational leadership: a model for leading telecommuters. Journal of Nursing Management, 13 (6), 483-489. https://doi.org/10.1111/j.1365-2934.2005.00573.x 
Fiedler, F.E. (1967). A Theory of Leadership Effectiveness, New York: McGraw-Hill.

Goleman, D. (2000). Leadership that gets results. Harvard business review, 78 (2), 4-17.

Goodson, J.R., McGee, G.W., \& Cashman, J.F. (1989). Situational leadership theory: a test of leadership prescriptions. Group and Organizational Studies, 14 (4), 446-61. https://doi.org/10.1177/105960118901400406

Graeff, C.L. (1983). The Situational Leadership Theory a critical review. Academy of Management Review, 8 (2), 285-291. https://doi.org/10.2307/257756

Graeff, C.L. (1997). Evolution of situational leadership theory: a critical review. Leadership Quarterly, 8 (2), 153-70. https://doi.org/10.1016/S1048-9843(97)90014$\underline{x}$

Hallinger, P. (2011). Leadership for learning: lessons from 40 years of empirical research. Journal of Educational Administration, 49 (2), 125-142. https://doi.org/10.1108/09578231111116699

Hersey, P., \& Blanchard, K. H. (1977). Management of organizational behavior: Utilizing human resources (3th ed.). Englewood Cliffs, NJ: Prentice Hall.

Hersey, P., \& Blanchard, K.H. (1984). The Management of Organizational Behavior (4th ed.). Englewood Cliffs, NJ: Prentice Hall.

Hersey, P., Blanchard, K.H., \& Johnson, D.E. (1996). Management of organizational behavior: Utilizing human resources (7th ed.). Upper Saddle River, NJ: Prentice Hall.

Hersey, P., Blanchard, K.H., \& Johnson, D.E. (2001). Management of Organizational Behavior (8th ed.) Englewood Cliffs, NJ: Prentice Hall.

Hersey, P., Blanchard, K.H., \& Johnson, D.E. (2013). Management of organizational behavior: Leading human resources (10th ed.). Upper Saddle River, NJ: Prentice Hall.

Hersey, P., \& Blanchard, K.H. (1969). Life-cycle theory of leadership. Training \& Development Journal, 23, 26-34.

Hoption, C., Barling, J., \& Turner, N. (2013). It's not you, it's me: transformational leadership and self-deprecating humor. Leadership \& Organization Development Journal, 34 (1), 4-19. https://doi.org/10.1108/01437731311289947

House, R.J. (1971). A path-goal theory of leader effectiveness. Administrative Science Quarterly, 16 (3) 321-339. https://doi.org/10.2307/2391905

Kaifi, B. A., Noor, A. O., Nguyen, N. L., Aslami, W., \& Khanfar, N. M. (2014). The importance of situational leadership in the workforce: A study based on gender, place of birth, and generational affiliation. Journal of Contemporary Management,3 (2), 29-40.

Lacey, J. M. (2019). Student Development and Studio Management in Applied Music Teaching through Implementation of the Situational Leadership Model.

Lam, C.S., \& O'Higgins, E.R.E. (2012). Enhancing employee outcomes: the interrelated influences of managers' emotional intelligence and leadership style. Leadership \& Organization Development Journal, 33 (2), 149-174. https://doi.org/10.1108/01437731211203465

Leković, B., \& Marić, S. (2016). Innovativeness as a source of competitive advantage for entrepreneurial ventures and small business. Strategic Management, 21 (3), 312.
Luo, H., \& Liu, S. (2014). Effect of situational leadership and employee readiness match on organizational citizenship behavior in China. Social Behavior and Personality: an international journal, 42 (10), 1725-1732. https://doi.org/10.2224/sbp.2014.42.10.1725

Majeed, N., Ramaya, T., Mustamil, N., Nazri, M., \& Jamshed, S. (2017). Transformational Leadership and Organizational Citizenship Behavior: Modeling Emotional Intelligence as Mediator. Management and Marketing. Challenges for the Knowledge Society, 12 (4), 571-590. https://dx.doi.org/10.1515/mmcks-2017$\underline{0034}$

Nahavandi, A. (1997). The Art and Science of Leadership. Englewood Cliffs, NJ: Prentice Hall.

Nilsson, K., \& Furaker, C. (2012). Learning leadership through practice - healthcare managers' experience. Leadership in Health Services, 25 (2), 106-122. https://doi.org/10.1108/17511871211221037

Northouse, P.G. (2004). Leadership: Theory and Practice (2nd ed.). London: Sage.

Northouse, P.G. (2007). Leadership: Theory and Practice. Thousand Oaks, CA: Sage Publications.

Papworth, M. A., Milne, D., \& Boak, G. (2009). An exploratory content analysis of situational leadership. Journal of Management Development, 28(7), 593-606. https://doi.org/10.1108/02621710910972706

Ralph, E. G. (2004). Developing managers' effectiveness: A model with potential. Journal of Management Inquiry, 13 (2), 152-163. https://doi.org/10.1177/1056492604265222

Reddin, W.J. (1967). The 3-D management style theory. Training and Development Journal, 21 (4), 8-17.

Rosiński, J. (2017). The Negative Organisational Consequences of Average Leadership Skills. Case Studies Based on Ken Blanchard's Paradigm. International Journal of Contemporary Management, 16 (4), 165-184. https://doi.org/10.4467/24498939IJCM.17.043.8266

Rowold, J., \& Borgmann, L. (2013). Are leadership constructs really independent? Leadership \& Organization Development Journal, 34 (1), 20-43. https://doi.org/10.1108/01437731311289956

Salehzadeh, R. (2017). Which types of leadership styles do followers prefer? A decision tree approach. International Journal of Educational Management, 31 (7), 865-877. https://doi.org/10.1108/lJEM-04-2016-0079

Salehzadeh, R., Shahin, A., Kazemi, A., \& Shaemi Barzoki, A. (2015). Proposing a new approach for evaluating the situational leadership theory based on the Kano model: The case of university students. International Journal of Public Leadership, 11 (1), 4-20. https://doi.org/10.1108//JPL-05-2014-0003

Silverthorne, C. (2000). Situational Leadership Theory in Taiwan: A different culture perspective. Leadership and Organization Development Journal, 21 (2), 68-74. https://doi.org/10.1108/01437730010318156

Silverthorne, C., \& Wang, T. (2001). Situational leadership style as a predictor of success and productivity among Taiwanese business organizations. The Journal of Psychology, 135 (4), 399-412. https://doi.org/10.1080/00223980109603707

Stojanović, S., \& Marić, S. (2018). Communication as a measure of leadership performance. Anali Ekonomskog fakulteta u Subotici, (40), 81-94. https://doi.org/10.5937/AnEkSub1840081S 
Thompson, G., \& Vecchio, R.P. (2009). Situational leadership theory: a test of three versions. The Leadership Quarterly, 20 (5), 837-848. https://doi.org/10.1016/j.leaqua.2009.06.014

Thompson, G., \& Glasø, L., (2015). Situational leadership theory: a test from three perspectives. Leadership \& Organization Development Journal, 36 (5), 527-544. https://doi.org/10.1108/LODJ-10-2013-0130

Tortorella, G., \& Fogliatto, F. (2017). Implementation of lean manufacturing and situational leadership styles: An empirical study. Leadership \& Organization

Development Journal, 38 (7), 946-968.

https://doi.org/10.1108/LODJ-07-2016-0165

\section{$\triangle$ Correspondence}

\section{Slobodan Maric}

University of Novi Sad, The Faculty of Economics Subotica 9 - 11 Segedinski put, 24000, Subotica, Republic of Serbia

E-mail: marics@ef.uns.ac.rs
Vecchio, R.P. (1987). Situational leadership theory: an examination of a prescriptive theory. Journal of Applied Psychology, 72 (3), 444-51.

https://doi.org/10.1037/0021-9010.72.3.444

Vecchio, R.P., Bullis, R.C., \& Brazil, D.M. (2006). The utility of situational leadership theory: a replication in a military setting. Small Group Research, 37 (5), 407-24. https://doi.org/10.1177/1046496406291560

Yukl, G. (2006). Leadership in Organizations (6th ed.). Englewood Cliffs, NJ: Prentice Hall. 